\title{
PENGARUH MODEL BRAIN BASED LEARNING UNTUK MENINGKATKAN KEMAMPUAN KONEKSI MATEMATIS DAN PENCAPAIAN SELF CONCEPT SISWA
}

\author{
Mekarina \\ SMAN 3 Pekanbaru, Indonesia \\ Email: merimatika@gmail.com
}

\begin{abstract}
Abstrak
Tujuan penelitian ini menganalisis peningkatan kemampuan koneksi matematis dan self concept siswa dengan model brain based learning (BBL) dengan pendekatan saintifik. Adapun latar belakang penelitian ini adalah realita di lapangan menunjukkan bahwa kemampuan koneksi matematis siswa belum sesuai dengan yang diharapkan. Salah satu faktor penyebab permasalahan tersebut adalah pembelajaran yang tidak memberikan keleluasaan kepada siswa untuk memberdayakan potensi otak secara optimal. Hal ini mengakibatkan siswa mengalami kesulitan mengaitkan antar materi dan tingkat kepercayaan diri siswa yang kurang. Penelitian ini menggunakan pendekatan kuantitatif dengan metode eksperimen kuasi. Sampel pada penelitian ini adalah 37 siswa pada kelas kontrol dan 36 pada kelas eksperimen. Instrumen yang digunakan tes kemampuan koneksi matematis dan angket self concept. Hasil penelitian adalah: 1) peningkatan kemampuan koneksi matematika dengan model BBL lebih tinggi daripada dengan pendekatan saintifik; 2) pencapaian self concept siswa dengan model BBL lebih baik daripada dengan pendekatan saintifik; 3) terdapat hubungan antara kemampuan koneksi matematika dan self concept siswa dengan model BBL. Berdasarkan hasil penelitian, diharapkan peneliti berikutnya bisa memilih metode yang dapat mendorong tumbuh kembangnya self concept positif siswa, agar mempengaruhi keyakinan siswa tehadap kemampuan dirinya, dan pada akhirnya berpengaruh terhadap pencapaian prestasi belajar siswa.
\end{abstract}

Kata Kunci: Brain Based Learning; pendekatan saintifik; kemampuan koneksi matematis; Self Concept
Abstract
The purpose of this study was to analyze the improvement of students' mathematical connection skills and self-concept with a brain based learning (BBL) model with a scientific approach. The background of this research is that the reality on the ground shows that students' mathematical connection abilities are not as expected. One of the factors causing these problems is learning that does not provide flexibility for students to optimally empower the potential of the brain. This resulted in students having difficulty connecting between materials and the level of student confidence that was lacking. This study uses a quantitative approach with a quasi-experimental method. The sample in this study were 37 students in the control class and 36 in the

$\begin{array}{ll}\text { How to cite: } & \text { Mekarina, M., (2021) Pengaruh Model Brain Based Learning untuk Meningkatkan Kemampuan Koneksi } \\ & \text { Matematis dan Pencapaian Self Concept Siswa. Syntax Idea, 3(9), https://doi.org/10.36418/syntax- } \\ & \text { idea.v3i9.1490 } \\ \text { E-ISSN: } & 2684-883 X \\ \text { Published by: } & \text { Ridwan Institute }\end{array}$


experimental class. The instrument used is a mathematical connection ability test and a self-concept questionnaire. The results of the study are: 1) the increase in mathematical connection ability with the BBL model is higher than with the scientific approach; 2) the achievement of students' self-concept with the BBL model is better than the scientific approach; 3) there is a relationship between the ability of mathematical connections and students' self-concept with the BBL model. Based on the results of the study, it is hoped that the next researcher can choose a method that can encourage the growth and development of students' positive self-concepts, in order to influence students' beliefs about their abilities, and ultimately affect student achievement.

Keywords: brain based learning; scientific approach; mathematical connection ability; self concept

Received: 2021-08-22; Accepted: 2021-09-05; Published: 2021-09-20

\section{Pendahuluan}

Matematika merupakan ilmu universal yang berguna bagi kehidupan manusia dan mendasari perkembangan teknologi modern, serta mempunyai peran penting dalam berbagai disiplin ilmu. Selain itu matematika sebagai alat untuk melatih berpikir analitis dan sistematis, sehingga matematika menjadi semakin penting untuk dipelajari. Oleh karena itu matematika diajarkan pada semua jenjang pendidikan di sekolah yang diperkuat dengan kurikulum pendidikan dasar dan menengah yang menjadikan matematika sebagai pelajaran wajib. Di dukung oleh Permendikbud Nomor 58 Tahun 2014 bahwa matematika menjadi mata pelajaran wajib di tingkat SD, SMP, dan SMA.

Pembelajaran matematika tidak hanya mengharuskan siswa sekedar mengerti materi yang dipelajari, akan tetapi belajar dengan pemahaman dan aktif membangun pengetahuan baru dari pengalaman dan pengetahuan yang dimiliki agar pembelajarannya lebih bermakna. Agar hal tersebut dapat terwujud, National Council of Teachers of Mathematics (NCTM) (2000) menetapkan standar proses yang perlu dimiliki siswa melalui pembelajaran matematika, yaitu: (1) komunikasi matematis; (2) penalaran dan pembuktian matematis; (3) pemecahan masalah matematis; (4) koneksi matematis; (5) representasi matematis.

Koneksi matematis merupakan keterkaitan antara topik matematika sangat erat sebagai akibat bahwa matematika sebagai ilmu yang terstruktur dan sistematis, yang berarti bahwa konsep dan prinsip dalam matematika saling berkaitan antara satu dengan lainnya. (Molina, 2014) menyatakan bahwa, salah satu cara untuk meningkatkan kualitas mengajar adalah dengan menemukan dan menggunakan koneksi diantara konsep-konsep dan ide-ide matematika. Sementara (Hendriana \& Soemarmo, 2014) menyatakan bahwa dengan koneksi matematis dapat membantu siswa dalam menyelesaikan tugas pemecahan masalah melalui keterkaitan antar konsep matematika dan antara konsep matematika dengan konsep dalam disiplin ilmu lain. Tujuan mengembangkan kemampuan koneksi matematis agar dapat membuka wawasan dan 
pemikiran siswa terhadap matematika, sehingga menimbulkan sikap yang positif terhadap matematika itu sendiri.

Realita di lapangan kemampuan koneksi matematis siswa belum berkembang dengan baik. Hal ini tergambar dari hasil studi pendahuluan berupa tes materi prasyarat yang dilakukan pada sampel penelitian, siswa mengalami kesulitan dalam mengingat materi yang terkait dengan penyelesaian soal dan kehidupan sehari-hari. Selain itu banyak siswa yang belum bisa memahami permasalahan dengan baik. Penelitian yang dilakukan di Sekolah Menengah Atas (SMA) oleh (Siahaan, 2012) dengan permasalahan bahwa kemampuan koneksi antar topik matematika tergolong rendah. Hal ini terjadi karena topik matematika yang harus dikaitkan dengan penyelesaian soal, sehingga memerlukan jangkauan pemikiran yang tinggi. Selain itu (Haety, 2013) menyatakan bahwa koneksi matematis siswa belum dikembangkan secara optimal, sehingga mempengaruhi hasil belajar matematika.

Meningkatkan kemampuan koneksi matematis siswa, guru perlu memberikan kepada siswa berbagai masalah nyata agar siswa terbiasa menghubungkan ide-ide untuk memecahkan permasalahan yang ada. Apabila siswa mampu menghubungkan konsep yang ada dan mudah dalam memunculkan ide, maka siswa memiliki keyakinan diri dalam belajar matematika. Keyakinan diri siswa tersebut erat kaitannya dengan self concept siswa.

Self concept siswa selama pembelajaran matematika dinamakan self concept matematis. Self concept matematis merupakan persepsi siswa terhadap kompetensi matematis yang mereka miliki dan kepercayaan terhadap kemampuan diri mereka yang berkaitan erat dengan keberhasilan pembelajaran. Indikator self concept matematis antara lain: (1) kemandirian dalam mempelajari materi matematika, siswa memaksimalkan potensi pikiran yang dimiliki; (2) keyakinan dalam mengatasi masalah, siswa yakin dalam memberikan jawaban; (3) rasa tanggung jawab terhadap diskusi, setiap anggota kelompok aktif berpendapat; (4) keaktifan saat pembelajaran, siswa mendominasi pembelajaran. Interaksi setiap siswa dengan siswa yang lain akan membentuk self concept yang berbeda. Siswa yang bekerja secara individu, akan memiliki self concept yang cenderung negatif, sebaliknya apabila siswa berdiskusi secara kelompok maka self concept cenderung lebih positif.

Berdasarkan hasil tanya jawab dan angket terbuka yang diberikan kepada siswa sebelum dilakukan penelitian, banyak siswa memberikan tanggapan negatif terhadap pelajaran matematika seperti menilai pelajaran matematika sulit, banyak yang tidak menyukai pelajaran matematika. Di samping itu rasa percaya diri dan tingkat keyakinan siswa dengan kemampuan dirinya masih kurang seperti penelitian yang dilakukan di SMA (Sartika \& Jamiah, 2014). Selanjutnya (Sumartini, 2015) menyatakan bahwa dalam pembelajaran matematika, siswa masih kurang memiliki self concept yang positif. Dari hasil analisa penelitian sebelumnya menunjukkan bahwa self concept siswa masih rendah. Hal ini dapat disebabkan oleh faktor internal dan eksternal siswa seperti penggunaan metode pembelajaran yang belum memaksimalkan fungsi otak siswa dan pembelajaran yang belum bisa meningkatkan rasa percaya diri siswa. 
Siswa dihadapkan kepada beban pendidikan yang terlalu banyak dan pencapaian yang terlalu tinggi dikarenakan lingkungan yang sangat kompetitif. Selain itu sistem pendidikan dan lingkungan tidak memberikan ruang yang cukup untuk mengembangkan kemampuan koneksi matematis siswa di sekolah. Menurut (Andinny, 2015), individu yang mempunyai kemampuan self concept yang positif akan mempunyai kemampuan untuk menyesuaikan diri lebih baik, menunjukkan kemampuan kognitif yang dimiliki dengan lebih baik serta dapat menghindarkan diri dari reaksi psikis negatif. Untuk itu guru perlu menggunakan prinsip pembelajaran yang bisa meningkatkan self concept yang positif siswa.

Prinsip pembelajaran dapat dituangkan dalam suatu model, strategi, metode pembelajaran sehingga pelaksanaan pembelajaran di kelas menjadi lebih bermakna dan kemampuan siswa yang diharapkan dapat tercapai. Salah satu strategi pembelajaran yang bisa dilakukan adalah dengan menggunakan suatu model pembelajaran yang dapat memaksimalkan fungsi otak sehingga kemampuan koneksi matematis siswa bisa tercapai serta konsep diri siswa untuk belajar matematika bisa muncul. Berdasarkan pemaparan sebelumnya berarti dibutuhkan sebuah model pembelajaran yang diperkirakan dapat meningkatkan kemampuan koneksi matematis dan self concept siswa, yaitu dengan model Brain Based Learning (BBL). BBL adalah model pembelajaran yang diselaraskan dengan cara kerja otak dan didesain secara alamiah untuk belajar (Jensen, 2008).

Tahap pembelajaran BBL yang diungkapkan Jensen dalam bukunya yaitu tahap pra-pemaparan, persiapan, inisiasi dan akuisisi, elaborasi, inkubasi dan memasukkan memori, verifikasi dan pengecekan keyakinan, dan yang terakhir adalah perayaan dan integrasi. Strategi utama yang dapat dikembangkan dalam implementasi Brain Based Learning yaitu: (1) menciptakan lingkungan belajar yang menantang kemampuan berpikir siswa; (2) menciptakan lingkungan pembelajaran yang menyenangkan; dan (3) menciptakan situasi pembelajaran yang aktif dan bermakna bagi siswa (Sapa'at, 2009). Berdasarkan strategi tersebut, pembelajaran dengan menggunakan model BBL dalam pembelajaran matematika bisa memberikan kesempatan pada siswa untuk mengasah kemampuan berpikir, khususnya kemampuan berpikir matematis.

Penggunaan model BBL dalam pembelajaran matematika, diharapkan siswa mempunyai sikap yang positif terhadap pelajaran matematika. Sikap yang positif seperti menyukai matematika, bertanggung jawab dengan tugas dan aktif dalam pembelajaran. Hal ini erat hubungannya dengan self concept siswa dalam pembelajaran matematika. Menurut (Ayodele, 2011) menyatakan bahwa siswa yang memiliki self concept yang positif, prestasi belajar matematika lebih baik. Hal yang serupa diungkapkan oleh (Yara, 2010) dalam penelitiannya bahwa, siswa yang memiliki self concept yang positif dan tinggi dapat mengerjakan matematika dengan baik. Dengan demikian dapat dikatakan bahwa dalam mempelajari matematika dibutuhkan self concept yang positif dari siswa untuk mencapai hasil belajar yang maksimal.

Berdasarkan uraian sebelumnya, dengan adanya model BBL diharapkan dapat mengoptimalkan kerja otak siswa, menjadikan siswa yakin dengan kemampuannya, 
menyukai pelajaran matematika dan pada akhirnya dapat meningkatkan prestasi siswa. Dari hal ini sangat menarik dan perlu dilakukan suatu studi mengenai alternatif pembelajaran matematika dengan model Brain Based Learning yang berhubungan dengan kemampuan koneksi matematis serta self concept siswa. Selain itu dalam penarikan kesimpulan, penting untuk diketahui hubungan (korelasi) antara kemampuan koneksi matematis dan self concept yang ada dalam penelitian ini. Maka dari itu, penulis melakukan penelitian mengenai pengaruh model Brain Based Learning terhadap peningkatan kemampuan koneksi matematis dan pencapaian self concept siswa. Berdasarkan latar belakang tersebut, rumusan masalah yaitu: (1) apakah peningkatan kemampuan koneksi matematis siswa yang memperoleh pembelajaran dengan model brain based learning lebih tinggi daripada siswa yang memperoleh pembelajaran dengan pendekatan saintifik; (2) apakah self concept siswa yang memperoleh pembelajaran dengan model brain based learning lebih baik daripada siswa yang memperoleh pembelajaran dengan pendekatan saintifik; (3) apakah terdapat korelasi antara kemampuan koneksi matematis dan self concept siswa yang mendapatkan pembelajaran dengan model brain based learning?. Penelitian penting dilakukan untuk melihat keefektifan model ini terhadap konsep diri siswa, yang mana hal ini sangat berpengaruh terhadap motivasi belajar siswa (Mekarina, 2017). Sehingga penelitian sekarang merupakan lanjutan dari penelitian sebelumnya dengan menggunakan variabel yang berbeda.

\section{Metode Penelitian}

Metode penelitian yang digunakan dalam penelitian ini adalah eksperimen kuasi. Hal ini disebabkan tidak memungkinkan pemilihan sampel secara acak karena telah terbentuknya satu kelompok utuh seperti kelompok siswa dalam satu kelas. Jika dilakukan pengelompokan secara acak maka akan menyebabkan kekacauan jadwal pelajaran. Adapun desain penelitian yang digunakan dalam penelitian ini adalah pretest-posttest design disebut sebagai non equivalent control group design. Desain ini mirip dengan pretest-posttest di dalam true experiment namun tidak dilakukan pemilihan sampel secara acak. Desain dalam penelitian ini digambarkan sebagai berikut (Creswell, 2017):

\begin{tabular}{llll}
\hline Kelas eksperimen & $\mathrm{O}$ & $\mathrm{X}$ & $\mathrm{O}$ \\
\hline Kelas kontrol & $\mathrm{O}$ & & $\mathrm{O}$ \\
\hline
\end{tabular}

\section{Keterangan:}

Pretes dan postes (tes kemampuan koneksi)

$\mathrm{X}$ : Perlakuan pembelajaran melalui Brain Based Learning.

Populasi dalam penelitian ini adalah siswa-siswa kelas XI SMA di Kabupaten Bandung Barat. Pengambilan sampel dilakukan menggunakan teknik purposive sampling. Hal ini berarti pengambilan sampel yang akan digunakan dalam penelitian ini 
berdasarkan pertimbangan tertentu (Sugiyono, 2016). Pengambilan sampel dengan teknik ini agar penelitian dapat berlangsung tanpa mengubah jadwal yang telah ditetapkan dari awal oleh sekolah. Kelas yang menjadi sampel penelitian terdiri dari dua kelas yaitu kelas eksperimen yang menggunakan pembelajaran dengan model brain based learning dan kelas kontrol yang menggunakan pembelajaran dengan pendekatan saintifik.

Data pada penelitian ini diperoleh dari instrumen tes kemampuan koneksi matematis, serta angket self concept. Tes kemampuan koneksi matematis diberikan sebelum dan sesudah proses pembelajaran, sedangkan angket self concept diberikan di akhir pembelajaran. Data hasil pretest dan postest kemampuan koneksi matematis dari kelas eksperimen dan kontrol dihitung skor N-gain sebelum melakukan uji hipotesis. Sedangkan skala self concept siswa dianalisis dan ditafsirkan berdasarkan interpretasi skala tanggapan untuk mengetahui kategori self concept siswa dan menguji hipotesis dilakukan dengan uji nonparametrik.

\section{Hasil dan Pembahasan}

\section{A. Hasil Penelitian}

Pada aspek kemampuan koneksi matematis memperlihatkan bahwa skor ratarata pretes kelas eksperimen lebih rendah dibandingkan kelas kontrol dengan selisih skor rata-rata sebesar $-0,13 \%$. Namun, skor rata-rata postes kelas eksperimen lebih tinggi dibandingkan kelas kontrol dengan selisih sebesar 1,15\%. Setelah pembelajaran diberikan selisih postes dan pretes kelas kontrol lebih rendah dibandingkan dengan kelas eksperimen. Selanjutnya simpangan baku kelas eksperimen juga lebih tinggi dari simpangan baku kelas kontrol. Artinya kemampuan siswa di kelas yang memperoleh pembelajaran dengan model brain based learning lebih beragam.

Bila dikaitkan dengan n-gain memperlihatkan bahwa kelas kontrol memiliki peningkatan yang lebih rendah dibandingkan kelas eksperimen. Namun, n-gain kemampuan koneksi matematis kelas yang memperoleh pembelajaran dengan model brain based learning lebih tinggi dibandingkan kelas yang menggunakan pendekatan saintifik, namun kedua kelas ada pada kategori $n$-gain yang sama, yaitu sedang.

Setelah diketahui bahwa salah satu skor $N$-gain kemampuan koneksi matematis berdistribusi tidak normal, oleh karena itu pengujian hipotesis dilanjutkan dengan menggunakan uji nonparametrik yaitu uji Mann Whitney-U. Hasil uji perbedaan skor $\mathrm{N}$-gain kemampuan koneksi matematis siswa yang memperoleh pembelajaran dengan model brain based learning dengan siswa yang memperoleh pembelajaran dengan pendekatan saintifik disajikan pada tabel berikut:

Tabel 1

Uji Perbedaan Skor N-gain Kemampuan Koneksi Matematis

\begin{tabular}{ccc}
\hline & Nilai & Keterangan \\
\hline Mann Whitney- $U$ & 440,500 & \\
\cline { 1 - 2 } & $-2,490$ & $\mathrm{H}_{0}$ ditolak \\
\hline
\end{tabular}




\begin{tabular}{cc}
\hline Asymp. Sig. (2-tailed) & 0,013 \\
\hline & (Sumber: Data Primer: 2018)
\end{tabular}

Berdasarkan hasil uji Mann-Whitney diperoleh nilai Asymp. Sig $=0,013$. Karena penelitian ini menggunakan uji satu pihak, sehingga nilai Sig. $(1$-tailed $)=$ $0,007<0,05$, artinya $\mathrm{H}_{0}$ ditolak. Hal ini berarti secara signifikansi peningkatan kemampuan koneksi matematis siswa yang memperoleh pembelajaran dengan model brain based learning lebih tinggi daripada siswa yang memperoleh pembelajaran dengan pendekatan saintifik.

Aspek lain adalah aspek self concept. Persentase pencapaian self concept kelas yang memperoleh pembelajaran dengan model brain based learning lebih 2,84\% dibandingkan kelas yang menggunakan pendekatan saintifik. Dari rataan pencapaian self concept siswa pada kelas eksperimen lebih mendekati skor maksimum dibandingkan dengan kelas kontrol. Selanjutnya, bila dilihat dari simpangan baku kelas eksperimen juga memiliki simpangan baku lebih tinggi dari kelas kontrol. Hal ini berarti, skor pencapaian self concept siswa pada kelas yang memperoleh pembelajaran dengan model brain based learning lebih beragam dibandingkan pada kelas yang menggunakan pendekatan saintifik. Berikut akan disajikan deskripsi skor self concept siswa pada kelas eksperimen dan kelas kontrol.

Tabel 2

Skor Self Concept Siswa

\begin{tabular}{lccc}
\hline \multicolumn{1}{c}{ Kelas } & Skor & $\boldsymbol{N}$ & $\overline{\boldsymbol{x}}$ \\
\hline Eksperimen & 2164 & 36 & 60,11 \\
\hline Kontrol & 2123 & 37 & 57,38 \\
\hline
\end{tabular}

(Sumber: Data Primer: 2018)

Dari Tabel 2 memperlihatkan rataan kelas eksperimen lebih besar dari kelas kontrol dengan selisish 2,73. Dari hal ini dapat disimpulkan bahwa self concept siswa yang memperoleh pembelajaran dengan model brain based learning lebih baik daripada siswa yang memperoleh pembelajaran dengan pendekatan saintifik.

Selain itu dilakukan juga uji korelasi antara kemampuan koneksi matematis dan self conept. Analisis ini digunakan untuk mengetahui ada tidaknya hubungan antara kemampuan koneksi matematis dan self concept siswa yang memperoleh pembelajaran dengan model brain based learning. Analisis data menggunkan uji Spearman. Kriteria uji yang diajukan adalah $\mathrm{H}_{0}$ ditolak jika nilai (sig.) $<\alpha$ dan $\mathrm{H}_{0}$ diterima jika nilai (sig.) $\geq \alpha$. Hasil analisis uji korelasi Spearman disajikan pada Tabel 4.20. Analisis ini untuk menjawab hipotesis yaitu: terdapat korelasi antara kemampuan koneksi matematis dan dan self concept siswa yang memperoleh pembelajaran dengan model brain based learning. Hasil uji korelasi disajikan pada tabel berikut ini 
Tabel 3

Uji korelasi Kemampuan Koneksi Matematis dan Self Concept

\begin{tabular}{cccc}
\hline $\boldsymbol{N}$ & Sperman's rho & Sig (2-tailed) & Keterangan \\
\hline 36 & 0,430 & 0,009 & $\mathrm{H}_{0}$ ditolak \\
\hline
\end{tabular}

(Sumber: Data Primer: 2018)

Berdasarkan Tabel 3 besarnya korelasi antara kemampuan koneksi matematis dan self concept siswa adalah 0,430 ysng termasuk ke dalam kategori korelasi sedang. Nilai signifikansi untuk uji korelasi adalah $0,009<0,05$, sehingga $\mathrm{H}_{0}$ ditolak. Dengan kata lain terdapat korelasi antara kemampuan koneksi matematis dan selfconcept siswa. Kesimpulannya adalah terdapat korelasi antar kemampuan koneksi matematis dan self concept siswa yang memperoleh pembelajaran dengan model brain based learning.

\section{B. Pembahasan}

\section{Peningkatan Kemampuan Koneksi Matematis}

Bagian ini membahas mengenai rumusan masalah, yaitu apakah peningkatan kemampuan koneksi matematis siswa yang memperoleh pembelajaran dengan model brain based learning lebih tinggi daripada siswa yang memperoleh pembelajaran dengan pendekatan saintifik. Hipotesis penelitian dari rumusan masalah ini adalah peningkatan kemampuan koneksi matematis siswa yang memperoleh pembelajaran dengan model brain based learning lebih tinggi daripada siswa yang memperoleh pembelajaran dengan pendekatan saintifik. Hasil yang diperoleh pada penelitian ini sejalan dengan hipotesis penelitian tersebut. Tujuan dari penelitian ini adalah untuk mengetahui peningkatan kemampuan koneksi matematis siswa yang memperoleh pembelajaran dengan model brain based learning dan siswa yang memperoleh pembelajaran dengan pendekatan saintifik. Selanjutnya dilakukan pengolahan dan analisis data pretes dan N-gain kemampuan koneksi matematis.

Analisis awal mengenai skor pretes pada kelas yang memperoleh pembelajaran dengan model brain based learning dan kelas yang memperoleh pembelajaran dengan pendekatan saintifik menunjukkan bahwa rata-rata kemampuan koneksi matematis sebelum pembelajaran tidak berbeda secara signifikan. Hal ini berarti sebelum pembelajaran dilaksanakan, tidak terdapat perbedaan kemampuan awal koneksi matematis antara kedua kelas tersebut. Dari kondisi awal terlihat bahwa kedua kelas yang menjadi subyek penelitian memang belum mendapatkan materi turunan fungsi sebagai materi yang diajarkan dalam penelitian ini. Selanjutnya, setelah mendapatkan perlakuan dalam pembelajaran, dilakukan postes untuk mengetahui kemampuan akhir setelah pembelajaran di kedua kelas.

Dalam pembelajaran melalui model brain based learning, siswa diberikan kesiapan dalam menerima pembelajaran dengan melakukan senam otak. 
Permasalahan dirancang dalam konteks yang relevan dengan materi yang akan dipelajari untuk mendorong siswa dalam membangun konsep dan aktif dalam diskusi kelompok. Guru membimbing siswa melalui pertanyaan terarah, hal ini bertujuan untuk merangsang dan melatih siswa untuk mencari keterkaitan antara konsep-konsep dalam matematika. Selain itu guru memberikan pertanyaan dari hal yang sederhana sampai siswa bisa menghubungkan konsep yang ada melalui peta pikiran. Model ini juga mempunyai tahap pembelajaran yang berisi waktu untuk relaksasi, setelah itu siswa bisa memaksimalkan pemikirannya. Proses berpikir yang baik menjadikan siswa dengan mudah menentukan koneksi antara konsep matematika dan siswa dapat mengintegrasikan antar konsep ilmu matematika, dengan disiplin ilmu lain dan pada kehidupan nyata (Diana \& Irawan, 2017).

Menurut (Hendriana \& Soemarmo, 2014) menyatakan bahwa dengan koneksi matematis dapat membantu siswa dalam menyelesaikan tugas pemecahan masalah melalui keterkaitan antar konsep matematika dan antara konsep matematika dengan konsep dalam disiplin ilmu lain. Tujuan mengembangkan kemampuan koneksi matematis siswa agar dapat membuka wawasan dan pemikiran siswa terhadap matematika, sehingga akan menimbulkan sikap yang positif terhadap matematika itu sendiri. Hal ini juga sejalan pada tahap model brain based learning yaitu tahap inisiasi dan akuisisi. Tahap ini merupakan tahap penciptaan koneksi atau pada saat neuron saling berkomunikasi satu sama lain (Jensen, 2008).

Berdasarkan perbandingan aktivitas siswa di kelas yang menggunakan model brain based learning dan kelas yang menggunakan pendekatan saintifik, dapat memberikan penjelasan bahwa di kelas yang menggunakan model brain based learning lebih mengeksplor kemampuan siswa dalam menentukan hubungan antara konsep. Selain itu adanya senam otak dan waktu rileksasi yang tidak ditemukan pada kelas yang menggunakan pendekatan saintifik, hal ini membuat siswa tidak merasa tertekan dalam belajar matematika dan memaksimalkan pemikirannya agar semua konsep saling terkoneksi dengan baik.

Pada pertemuan terakhir penelitian, siswa diberikan postes untuk mengetahui kemampuan siswa setelah pembelajaran. Hasil postes menunjukkan bahwa rata-rata hasil postes siswa kelas yang memperoleh pembelajaran dengan model brain based learning adalah 14,53, sedangkan rata-rata hasil postes siswa kelas yang memperoleh pembelajaran dengan pendekatan saintifik adalah 13,38. Hasil tersebut menunjukkan bahwa setelah pembelajaran dilaksanakan, skor postes kelas yang menggunakan model brain based learning mempunyai selisih 1,15 dengan kelas yang menggunakan pendekatan saintifik. Sementara itu, kualitas peningkatan kemampuan koneksi matematis siswa dapat dilihat dari klasifikasi skor $\mathrm{N}$-gain. Skor rata-rata $\mathrm{N}$-gain kelas yang memperoleh pembelajaran dengan model brain based learning adalah sebesar 0,59 atau berada pada klasifikasi sedang dan skor rata-rata $\mathrm{N}$-gain kelas yang memperoleh 
pembelajaran dengan pendekatan saintifik adalah sebesar 0,48 yang juga berada pada klasifikasi sedang. Walaupun kedua kelas berada pada klasifikasi sedang, namun secara statistika deskriptif rata-rata peningkatan kemampuan koneksi matematis siswa kelas yang memperoleh pembelajaran dengan model brain based learning lebih tinggi dibandingkan rata-rata peningkatan kelas kontrol.

Dalam pembelajaran guru harus memberi ruang dan kesempatan untuk mengeksplor kemampuan siswanya, dan mengutarakan ide, gagasan serta mengintegrasikan dan menggabungkan informasi dari sumber-sumber yang diperolehnya. Hal ini sejalan dengan pendapat (Siagian, 2016), bahwa pandangan belajar guru mempengaruhi cara guru mengajar siswa dan bagaimana siswa berpikir dalam mendapatkan pengetahuan. Oleh karena itu seorang guru matematika untuk mampu memfasilitasi siswanya agar dapat meningkatkan kemampuan berpikirnya, karena tujuan pembelajaran matematika seperti yang disebutkan sebelumnya di atas tidak akan berjalan sesuai dengan yang diharapkan jika tidak ditunjang dengan proses pembelajaran yang baik.

Hal ini didukung oleh dari hasil lembar observasi aktivitas guru dan aktivitas siswa pada setiap pertemuan. Dari lembar observasi dengan menggunakan model brain based learning, menjadikan siswa memaknai dan menikmati proses pembelajaran matematika, dimana aktivitas guru dan siswa setiap pertemuan semakin menuju arah yang positif. Selain melalui lembar observasi, dari hasil wawancara kepada beberapa siswa, mereka menyatakan bahwa model brain based learning dalam pembelajaran matematika belum pernah mereka dapatkan sebelumnya dan secara umum mereka senang dengan kegiatan pembelajaran tersebut. Siswa termotivasi untuk menyukai pelajaran matematika, perlu pikiran yang santai dan tidak terbebani dalam pembelajaran matematika, hal ini dikarenakan siswa diberikan waktu untuk mempersiapkan pikiran dengan adanya relaksasi. Pada akhirnya memudahkan siswa dalam mengoneksikan setiap konsep. Selain itu soal yang diberikan kepada siswa sesuai dengan karakteristik indikator kemampuan koneksi matematis.

\section{Self Concept Siswa}

Bagian ini membahas mengenai rumusan masalah, yaitu apakah self concept siswa yang memperoleh pembelajaran dengan model brain based learning lebih baik daripada siswa yang memperoleh pembelajaran dengan pendekatan saintifik. Hipotesis yang dikemukakan untuk rumusan masalah ini adalah self concept siswa yang memperoleh pembelajaran dengan model brain based learning lebih baik daripada siswa yang memperoleh pembelajaran dengan pendekatan saintifik. Hasil yang diperoleh pada penelitian ini sejalan dengan hipotesis penelitian tersebut.

Hasil penelitian menunjukkan bahwa pencapaian self concept siswa yang memperoleh pembelajaran dengan model brain based learning lebih baik daripada siswa yang memperoleh pembelajaran dengan pendekatan saintifik. Hal ini didasarkan pada perolehan rata-rata skor postes kelas yang memperoleh 
pembelajaran dengan model brain based learning lebih tinggi daripada kelas kontrol, sehingga memberikan dampak positif bagi siswa dalam mengembangkan pencapaian self concept. Ini berarti bahwa pembelajaran model brain based learning berpengaruh secara signifikan dalam pencapaian self concept siswa. Dilihat dari karakteristik pembelajaran model brain based learning yang digunakan pada pembelajaran matematika di kelas, akan memungkinkan tumbuhnya ketertarikan dan mampu mengenali kelebihan dan kelemahan diri, serta menjadikan siswa dapat mengikuti pembelajaran matematika dengan menyenangkan.

Hal ini diperkuat dengan pendapat (Obilor, 2011) dalam penelitiannya menunjukkan bahwa hubungan self concept terhadap prestasi sekolah siswa sangat spesifik. Ukuran prestasi akademik siswa berhubungan secara positif dengan self concept akademik siswa dan sangat berhubungan dengan keberhasilan pembelajaran. Berdasarkan pengujian statistik yang telah dilakukan disimpulkan bahwa pencapaian self concept siswa yang memperoleh pembelajaran dengan model brain based learning lebih baik daripada siswa yang memperoleh pembelajaran dengan pendekatan saintifik.

Dalam penelitian ini self concept menggunakan indikator antara lain: (1) menunjukkan kemauan, keberanian, kegigihan, kesungguhan, keseriusan, ketertarikan belajar matematika; (2) mampu mengenali kekuatan dan kelemahan diri sendiri dalam matematika; (3) menunjukkan kerja sama dan toleran kepada orang lain dalam belajar matematika; (4) menghargai pendapat orang lain dan diri sendiri saat belajar matematika; (5) menunjukkan kemampuan berkomunikasi dan tahu menempatkan diri dalam belajar matematika; (6) pandangan, manfaat dan kesukaan terhadap pelajaran matematika. Berikut jumlah skor jawaban siswa berdasarkan indikator self concept.

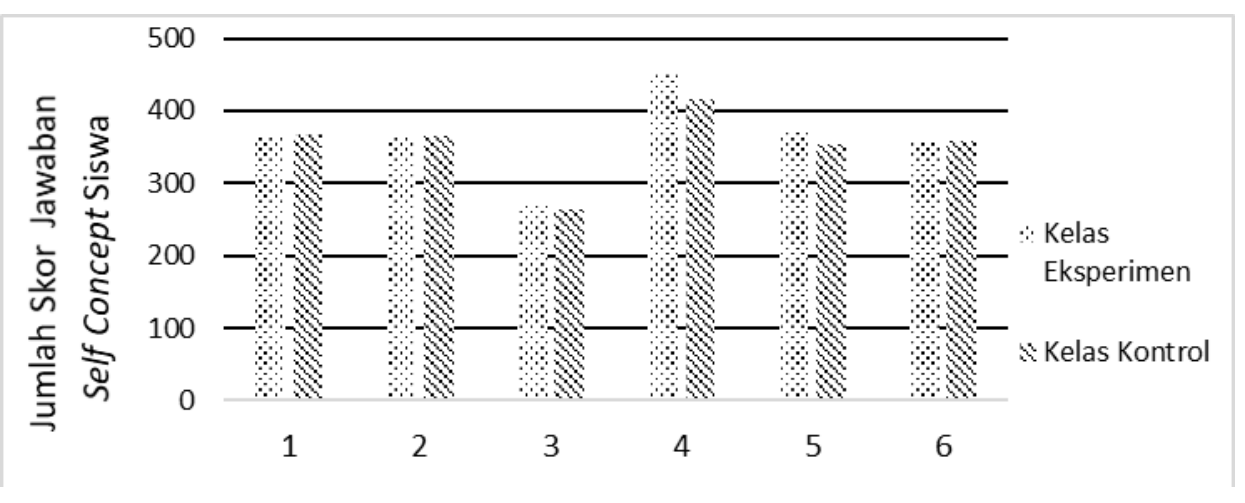

Gambar 1

Jumlah Skor Jawaban Self Concept Siswa

(Sumber: Data Primer: 2018)

Berdasarkan Gambar 1 di atas tampak bahwa secara keseluruhan jumlah skor self concept siswa kelas eksperimen lebih besar daripada kelas kontrol. 
Indikator yang paling menonjol di kelas eksperimen dibandingkan kelas kontrol adalah indikator menghargai pendapat orang lain dan diri sendiri saat belajar matematika. Siswa yang bisa menghargai dirinya, cenderung berusaha memperoleh segala hal yang diinginkan, salah satunya bisa menyelesaikan tugas yang diberikan guru, tanpa melihat jawaban teman.

Pembelajaran dengan model brain based learning yang dikemukakan oleh (Jensen, 2008) menjelaskan bahwa di antara tahapan pembelajaran ini siswa dituntut untuk mengeksplorasi ide-ide dan menghubungkan ide-ide tersebut. Adanya tahap pengungkapan ide tersebut menjadikan siswa mengetahui bahwa ide yang dimiliknya belum tentu akan sama dengan ide yang diberikan oleh teman-temannya. Siswa akan berusaha dalam menemukan pengetahuan baru berdasarkan ide-ide yang dimilikinya dan juga dari ide yang diberikan oleh teman-temannya, sehingga siswa bisa menyelesaikan tugas yang diberikan. Dengan adanya keberhasilan dalam menyelesaikan soal yang diperintahkan oleh guru, dapat meningkatkan konsep diri yang positif bagi siswa.

Berdasarkan hasil penelitian di atas, didapat bahwa rata-rata self concept siswa masih tergolong cukup, artinya mahasiswa pada proses pembelajaran belum menunjukkan rasa percaya diri dan keyakinan yang penuh atas kemampuannya dirinya. Dari kedua faktor itulah jelas bahwa hasil belajar siswa masih belum menunjukkan hasil yang optimal. Berdasarkan hasil analisis data, didapat bahwa kontribusi variabel self concept siswa mempengaruhi hasil kemampuan matematis. Hal ini dilihat dari pencapaian self concept kelas yang memperoleh pembelajaran dengan model brain based learning terhadap nilai kemampuan matematis siswa. Selain dari model yang digunakan guru, pencapaian self concept juga dipengaruhi oleh faktor lain, seperti kemampuan awal mahasiswa, motivasi baik itu dari dirinya sendiri, keluarga dan lingkungan (Pamungkas, 2015). Di samping itu faktor kematangan usia dimana siswa bisa mengembangkan self concept nya sehingga mereka lebih mampu mengevaluasi berbagai macam tekanan, tantangan yang ada di sekitar mereka.

\section{Hubungan antara Kemampuan Koneksi Matematis dan Self Concept}

Bagian ini membahas mengenai rumusan masalah, yaitu apakah terdapat korelasi antara kemampuan koneksi matematis dan self concept siswa yang mendapatkan pembelajaran dengan model brain based learning. Hipotesis penelitian dari rumusan masalah ini adalah terdapat korelasi antara kemampuan koneksi matematis dan self concept siswa yang mendapatkan pembelajaran dengan model brain based learning. Hasil yang diperoleh pada penelitian ini sejalan dengan hipotesis penelitian tersebut.

Besarnya korelasi antara kemampuan koneksi matematis dan self concept siswa adalah 0,430 yang termasuk ke dalam kategori korelasi sedang. Nilai signifikansi untuk uji korelasi adalah $0,009<0,05$, sehingga $\mathrm{H}_{0}$ ditolak. Dengan kata lain terdapat korelasi antara kemampuan koneksi matematis dan self concept siswa. Hal ini dapat dikatakan bahwa setelah diberikan pembelajaran dengan 
menggunakan model brain based learning, siswa yang mempunyai pencapaian self concept yang tinggi juga memiliki peningkatan kemampuan koneksi matematis yang tinggi. Demikian pula sebaliknya, jika peningkatan kemampuan koneksi matematis siswa rendah, maka pencapaian self concept siswa juga rendah.

Hasil di atas menunjukkan bahwa model brain based learning mempengaruhi kesiapan dan keinginan siswa untuk belajar, dan didukung oleh suasana belajar yang menyenangkan, sehingga siswa meningkatkan konsep diri (self concept) siswa. Lingkungan pendidikan dan iklim belajar yang baik memiliki peran penting dalam perkembangan pembelajaran siswa. Konsep diri yang baik mempengaruhi kemampuan siswa dalam belajar, dan akhirnya meningkatkan prestasi belajar. Lebih lanju (Ayodele, 2011) berpendapat bahwa siswa yang memiliki self concept yang positif, prestasi belajar matematikanya lebih baik. Jadi penggunaan model pembelajaran yang tepat dapat membantu meningkatkan kemampuan kognitif dan mempengaruhi pencapaian afektif siswa.

Selain itu hasil penelitian didukung juga dari hasil lembar observasi aktivitas siswa dan guru yang dilakukan pada setiap pertemuan di kelas yang menggunakan model brain based learning. Berdasarkan lembar observasi aktivitas siswa disimpulkan bahwa aktivitas siswa menuju arah yang positif pada setiap pertemuan dalam melakukan tahapan dari model brain based learning. Selain itu siswa antusias dalam belajar, hal ini terlihat dari usaha siswa dalam mengerjakan tugas dengan penuh tanggung jawab secara individu maupun kelompok. Keyakinan dan kesukaan siswa terhadap pembelajaran matematika semakin meningkat, hal ini terlihat dari motivasi dan kesungguhan siswa dalam memahami materi matematika semakin baik.

Lebih lanjut (Andinny, 2015) menjelaskan bahwa prestasi belajar adalah suatu penilaian akhir dari proses dan pengenalan yang berulang-ulang serta akan tersimpan dalam jangka waktu lama atau bahkan tidak akan hilang selamalamanya, karena prestasi belajar turut serta dalam membentuk pribadi yang lebih baik lagi. Prestasi Belajar tersebut ditunjukkan dengan nilai tes kemampuan kognitif yang diberikan oleh guru dalam kurun waktu tertentu. Melalui prestasi belajar ini siswa diharapkan mampu mengembangkan kemampuan pemahaman matematika dalam akademik.

Hasil penelitian di atas diperkuat oleh analisis jawaban siswa pada kelas yang memperoleh pembelajaran dengan model brain based learning yang memiliki self concept yang baik, maka hasil tes juga memperoleh hasil yang baik. Berikut contoh jawaban siswa yang memiliki skor self concept yang baik dalam menjawab soal tes kemampuan koneksi matematis. 


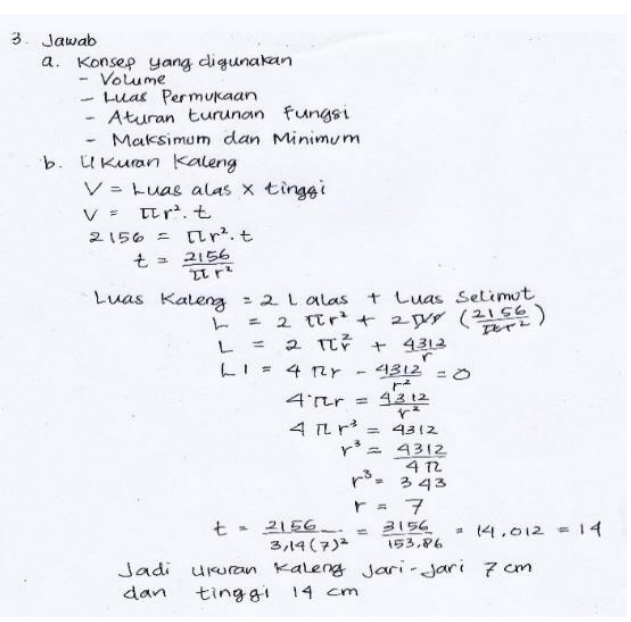

Gambar 2

\section{Contoh Jawaban Siswa Tes Kemampuan Koneksi Matematis}

Berdasarkan hasil jawaban siswa maka dapat disimpulkan bahwa siswa sudah dapat memaknai soal dan bisa mengaitkan konsep-konsep yang digunakan dalam penyelesaian soal tes. Selain itu siswa berusaha membuat langkah yang jelas dan memahami proses penyelesaian, sehingga menghasilkan kesimpulan yang benar, dan akhirnya hasil tes kemampuan koneksi matematis siswa menunjukkan hasil yang baik.

Keberhasilan pembelajaran berarti tujuan yang diinginkan tercapai, hal ini diketahui setelah diadakan evaluasi dan seperangkat item soal sesuai dengan rumusan beberapa indikator hasil belajar. Hasil analisis data di atas, menunjukkan bahwa antara self concept secara bersama-sama dapat mempengaruhi prestasi belajar matematika yaitu dalam kemampuan koneksi matematis siswa SMA. Hal tersebut diterangkan melalui hasil perhitungan korelasi yang menunjukan adanya pengaruh yang kuat antara self concept terhadap kemampuan koneksi matematis siswa.

\section{Kesimpulan}

Berdasarkan rumusan masalah, hasil penelitian, dan pembahasan diperoleh kesimpulan sebagai berikut. Peningkatan kemampuan koneksi matematis siswa yang memperoleh pembelajaran dengan model brain based learning lebih tinggi daripada siswa yang memperoleh pembelajaran dengan pendekatan saintifik. Berdasarkan pengalaman peneliti di lapangan, pelaksanaan model brain based learning membutuhkan waktu yang cukup lama dan perencanaan yang matang, serta didukung oleh kemampuan guru memberikan stimulus untuk meningkatkan respon yang positif dari siswa. Untuk itu diharapkan pada penelitian selanjutnya disusun bahan ajar yang lebih menarik dan variatif supaya peningkatannya lebih optimal.

Self concept siswa yang memperoleh pembelajaran dengan model brain based learning lebih baik daripada siswa yang memperoleh pembelajaran dengan pendekatan saintifik. Self concept siswa yang dianalisis pada penelitian ini terbatas hanya setelah 
enam kali pertemuan. Oleh karena itu, pada penelitian selanjutnya dapat dilakukan dalam jangka waktu yang cukup lama supaya dapat diamati peningkatannya dari sebelum diberi perlakuan hingga setelah diberi perlakuan, dan juga diamati perubahan self concept siswa dalam setiap pembelajaran.

Terdapat korelasi antara kemampuan koneksi matematis dan self concept siswa yang mendapatkan pembelajaran dengan model brain based learning. Guru hendaknya senantiasa menciptakan lingkungan belajar yang mendorong tumbuh kembangnya self concept positif siswa, agar mempengaruhi keyakinan siswa tehadap kemampuan dirinya, dan pada akhirnya berpengaruh terhadap pencapaian prestasi belajar, dengan memilih metode yang bisa mengembangkan self concept siswa. 


\section{BIBLIOGRAFI}

Andinny, Yuan. (2015). Pengaruh konsep diri dan berpikir positif terhadap prestasi belajar matematika siswa. Formatif: Jurnal Ilmiah Pendidikan MIPA, 3(2). Goggle Scholar

Ayodele, J. .. (2011). Self concept and performance of secondary school students in mathematics. Journal of Educational and Developmental Psychology, 1(1), 49-54.

Creswell, J. David. (2017). Mindfulness interventions. Annual Review of Psychology, 68, 491-516. Goggle Scholar

Diana, Risma Firda, \& Irawan, Edy Bambang. (2017). Proses Koneksi Matematis Siswa Bergaya Kognitif Reflektif Dalam Menyelesaikan Masalah Aljabar Berdasarkan Taksonomi Solo. Jurnal Kajian Pembelajaran Matematika, 1(1), 52-63. Goggle Scholar

Haety, Nonoy Intan. (2013). Pengaruh Model Pembelajaran Matematika Knisley terhadap peningkatan kemampuan koneksi Matematis siswa sma. Universitas Pendidikan Indonesia. Goggle Scholar

Hendriana, Heris, \& Soemarmo, Utari. (2014). Penilaian pembelajaran matematika. Bandung: Refika Aditama. Goggle Scholar

Jensen, Eric. (2008). Brain-Based Learning: Pembelajaran Berbasis Kemampuan Otak, Cara Baru dalam Pengajaran dan Pelatihan. Yogyakarta: Pustaka Pelajar.

Molina, C. (2014). Teaching mathematics conceptually. SEDL. Http://Www.Sedl.Org/Insight/1-4/Teaching Mathematics Coceptually.Pdf., 1(4). Goggle Scholar

Obilor, Isaac Esezi. (2011). Relationship between self-concept and mathematics achievement of senior secondary students in Port Harcourt Metropolis. Journal of Educational and Social Research, 1(4), 39. Goggle Scholar

Pamungkas, Aan Subhan. (2015). Kontribusi Self Concept Matematis dan Mathematics Anxiety terhadap Hasil Belajar Mahasiswa. Jurnal Dinamika Pendidikan, 8(2), 5560. Goggle Scholar

Sapa'at, A. (2009). Brain based learning. Retrieved from http://matematika.upi.edu/index.php/brain-based-learning/ pada tanggal 20 Januari 2017. Goggle Scholar

Sartika, Ita, \& Jamiah, Yulis. (2014). Kemampuan Pemecahan Masalah pada Materi Trigonometri Dikaji dari Self Concept Siswa Kelas XI IPA. Jurnal Pendidikan Dan Pembelajaran Khatulistiwa, 3(12). Goggle Scholar 
Siagian, Muhammad Daut. (2016). Kemampuan koneksi matematik dalam pembelajaran matematika. MES: Journal of Mathematics Education and Science, 2(1). Goggle Scholar

Siahaan, Friska Bernadette. (2012). Pengaruh Strategi REACT dan Sikap Siswa Terhadap Matematika dalam Peningkatan Kemampuan Koneksi Matematika Siswa SMA. Jurnal Paradikma, 5(02), 129-137. Goggle Scholar

Sugiyono. (2016). Metode penelitian pendidikan. Bandung: Alfabeta.

Sumartini, Tina Sri. (2015). Mengembangkan self concept siswa melalui model pembelajaran concept attainment. Mosharafa: Jurnal Pendidikan Matematika, 4(2), 48-57. Goggle Scholar

Yara, P. O. (2010). Students' self-concept and mathematics achievement in some secondary schools in southwestern Nigeria. European Journal of Social Sciences, 13(1), 127-132. Goggle Scholar

Copyright holder:

Mekarina (2021)

First publication right:

Syntax Idea

This article is licensed under:

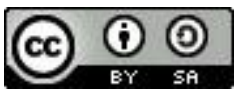

